\title{
Embryonic stimulation of ovine and bovine corpora lutea
}

\author{
J. D. Godkin, C. Coté and R. T. Duby \\ Department of Veterinary and Animal Sciences, Laboratory for Reproductive Physiology, \\ University of Massachusetts, Amherst, Massachusetts 01003, U.S.A.
}

\begin{abstract}
Summary. Preimplantation embryos, recovered from sheep on Days 13-15 of pregnancy, were incubated with luteal tissue from cyclic ewes. Extracts of ovine embryos were incubated with luteal tissue from cyclic Holstein cows. Er:abryos and embryo extracts significantly increased progesterone production by ovine and bovine luteal tissue in vitro. The embryos themselves did not produce measurable amounts of progesterone. We suggest that the ovine preimplantation embryo produces a substance with luteotrophic properties which contributes to the maintenance of early pregnancy.
\end{abstract}

\section{Introduction}

The maintenance of pregnancy is dependent upon coordinated interactions between the developing embryo and its dam. Establishment of the short-lived corpus luteum of the oestrous or menstrual cycle as the corpus luteum of pregnancy depends upon the presence of an embryo in the uterus in many species (Moor \& Rowson, 1966a, b; Heap, Perry \& Rowlands, 1967; Greenwald \& Rothchild, 1968; Knobil, 1973). Although the mechanism by which an embryo prevents regression of the corpus luteum is not well defined, it may produce a luteotrophic substance which maintains the corpus luteum in early pregnancy.

Blastocyst fluid from 6-day-pregnant rabbits has been reported to contain a substance similar to hCG and LH (Haour \& Saxena, 1974; Fujimoto, Euker, Riegel \& Dukelow, 1975), and an hCGlike substance has been detected on cell surfaces of the preimplantation mouse embryo by immunofluorescent staining (Wiley, 1974). In contrast, other investigators using sensitive in-vitro bioassay methods report that the rabbit blastocyst or blastocoelic fluid neither produces nor contains any hCG-like or LH-like substance (Sudanram, Connell \& Passantino, 1975; Holt, Heise, Wilson \& Keyes, 1976).

Embryo transfer experiments have demonstrated that in the sheep an embryo must be present within the uterus by the 12 th day of the oestrous cycle for the corpus luteum of the cycle to become the corpus luteum of pregnancy (Moor \& Rowson, 1966a, b). Additionally, intrauterine infusion of 14- or 15-day-old sheep embryo homogenates significantly prolongs the length of the oestrous cycle (Rowson \& Moor, 1967). In the present study we have examined the effects of preimplantation sheep embryos on ovine and bovine corpora lutea in vitro.

\section{Materials and Methods}

Adult ewes of mixed breeds were checked daily for oestrus with vasectomized rams. At 12 days after oestrus, the ewes were induced to superovulate by a single intramuscular injection of PMSG (Sigma Chemical Co.) and were mated at the subsequent heat with a fertile ram. The ewes were anaesthetized on the 13th-15th day of pregnancy and the uterus was exteriorized through a midventral incision. The embryos were obtained by flushing each uterine horn with $30 \mathrm{ml}$ sterile $0.9 \%$ $(\mathrm{w} / \mathrm{v}) \mathrm{NaCl}$. Corpora lutea (CL) were obtained from the ovaries of cyclic ewes via midventral 
laparotomy 12-14 days after oestrus. The embryos and CL were taken to the laboratory where the embryos were transferred to fresh incubation medium and the CL were trimmed of connective tissue and cut into slices approximately $0.5 \mathrm{~mm}$ thick. Random aliquots of luteal tissue were then weighed, transferred to $25 \mathrm{ml}$ Erlenmeyer flasks containing $5 \mathrm{ml}$ Krebs-Ringer-bicarbonate buffer (Krebs, 1950) containing $0.1 \mathrm{mg}$ glucose/ml. Because of the inherent variability of progesterone synthesis by CL tissue in vitro, each trial consisted of at least 2 control flasks and 2 flasks containing embryos. The flasks were incubated at $37^{\circ} \mathrm{C}$ in a shaker bath for $2 \mathrm{~h}$ in an atmosphere of $95 \%$ $\mathrm{O}_{2}: 5 \% \mathrm{CO}_{2}$. Tissue metabolism was terminated by placing the flasks in liquid $\mathrm{N}_{2}$ and the samples were stored at $-20^{\circ} \mathrm{C}$ until extracted. The luteal slices were homogenized with the incubation medium and extracted with anhydrous ether. Progesterone was isolated by submitting the organic residue

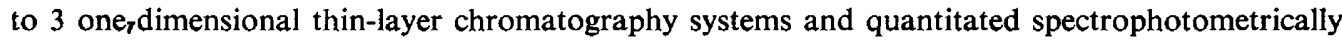
according to the procedure described by Hansel (1971). Briefly, sample residues were suspended in known amounts of redistilled ethanol and their absorbance of ultraviolet light was measured at $240 \mathrm{~nm}$ in a Bausch and Lomb 600 spectrophotometer. The influence of non-specific contaminants was minimized by taking measurements of each sample at 230 and $250 \mathrm{~nm}$ and correcting the reading at $240 \mathrm{~nm}$ through the use of the Allen factor (Allen, 1950). The amount of progesterone in a sample was determined by extrapolating the corrected $240 \mathrm{~nm}$ reading from a standard curve produced with known amounts of purified progesterone. Standard curves were all linear between 3 and 25 $\mu \mathrm{g} / \mathrm{ml}$ and standard deviations were all less than $0 \cdot 02$. Procedural losses were checked by the addition of $\left[{ }^{3} \mathrm{H}\right]$ progesterone to each flask after homogenization. All samples were corrected for $100 \%$ recovery and values were expressed as $\mu \mathrm{g}$ progesterone $/ \mathrm{g}$ luteal tissue $/ 2 \mathrm{~h}$.

To determine if substances produced by the ovine embryo stimulate progesterone synthesis in other species, ovine embryos were incubated alone in the Krebs-Ringer-bicarbonate incubation medium for $3 \mathrm{~h}$ at $37^{\circ} \mathrm{C}$, then flash-frozen and stored at $-20^{\circ} \mathrm{C}$. After thawing the cultures were centrifuged to remove cellular material. Aliquots of the supernatant (embryo extracts) were incubated for $2 \mathrm{~h}$ with slices of CL removed per vaginam from cyclic Holstein cows on Days 14 or 15 after oestrus.

The significance of differences between the means of treated and control samples was determined by analysis of variance (Steel \& Torrie, 1960).

\section{Results}

As shown in Table 1, the ovine preimplantation embryo stimulated a dramatic increase in progesterone synthesis in 9 out of 10 trials. The variability of control values between experiments is within the normal range experienced in our laboratory and may be due to differences in initial progesterone concentrations of individual CL. For this reason one CL was used for each experiment. The standard deviation of control values within experiments ranged from 1 to $11 \%$. The variability in the degree or responsiveness by luteal slices to the embryos may be explained by the fact that all flasks did not contain equal amounts of embryonic tissue. Although we attempted to use 1-2 embryos per flask, embryos varied in size and occasionally fragmented during flushing. For this reason, each embryo-treated flask is listed individually in Table 1 . No attempt was made to determine the viability of the embryos and this may account for the single failure to stimulate progesterone synthesis. In another experiment, we used embryos which were visibly degenerate; these embryos also failed to stimulate progesterone synthesis. To determine whether the embryos themselves were adding progesterone to the samples, 5 flasks of 1-2 embryos per flask were incubated alone and analysed for progesterone in the same way but no progesterone could be detected by the method used. When bovine luteal slices were incubated with aqueous extracts of bovine (cyclic, Days 12-18) endometrium or intestine there was no change in progesterone synthesis compared to that of controls.

Ovine embryo extracts significantly stimulated progesterone synthesis by hovine luteal tissue (Table 2). Preliminary data indicate that the luteotrophic properties of the extracts are non-dialysable and heat labile. 
Table 1. Total progesterone (mean \pm s.e.m.) produced by ovine luteal slices incubated for $2 \mathrm{~h}$ with and without ovine embryos

\begin{tabular}{|c|c|c|c|c|c|}
\hline \multirow[b]{2}{*}{$\mathrm{CL}$} & \multicolumn{2}{|c|}{ Control } & \multicolumn{3}{|c|}{ Treated } \\
\hline & $\begin{array}{l}\text { No. of } \\
\text { flasks }\end{array}$ & $\begin{array}{c}\text { Progesterone } \\
(\mu \mathrm{g} / \mathrm{g})\end{array}$ & $\begin{array}{l}\text { No. of } \\
\text { flasks }\end{array}$ & $\begin{array}{c}\text { Progesterone } \\
(\mu \mathrm{g} / \mathrm{g})\end{array}$ & $\begin{array}{c}\% \\
\text { increase }\end{array}$ \\
\hline \multirow[t]{2}{*}{ A } & 2 & $140.0 \pm 15.7$ & 2 & $203 \cdot 0$ & 44 \\
\hline & & & & 266.6 & 90 \\
\hline \multirow[t]{2}{*}{ B } & 2 & $102 \cdot 3 \pm 10 \cdot 3$ & 2 & $155 \cdot 2$ & 52 \\
\hline & & & & $92 \cdot 8$ & -9 \\
\hline \multirow[t]{2}{*}{ C } & 2 & $199.9 \pm 7.6$ & 2 & 351.7 & 76 \\
\hline & & & & 267.5 & 34 \\
\hline \multirow[t]{2}{*}{ D } & 2 & $177 \cdot 2 \pm 4 \cdot 7$ & 2 & $265 \cdot 3$ & 50 \\
\hline & & & & $299 \cdot 1$ & 69 \\
\hline \multirow[t]{2}{*}{ E } & 2 & $95 \cdot 2 \pm 1 \cdot 1$ & 2 & $162 \cdot 5$ & 71 \\
\hline & & & & $134 \cdot 3$ & 41 \\
\hline Overall & & $143.0 \pm 13.8$ & & $219 \cdot 8 \pm 26.0^{*}$ & $51 \cdot 8 \pm 8.8$ \\
\hline
\end{tabular}

* Significantly different from control value, $P<0.05$.

Table 2. Total progesterone (mean \pm s.e.m.) produced by bovine luteal slices incubated for $2 \mathrm{~h}$ with and without ovine embryo extracts

\begin{tabular}{|c|c|c|c|c|c|}
\hline \multirow[b]{2}{*}{ CL } & \multicolumn{2}{|c|}{ Control } & \multicolumn{3}{|c|}{ Treated } \\
\hline & $\begin{array}{l}\text { No. of } \\
\text { flasks }\end{array}$ & $\begin{array}{l}\text { Progesterone } \\
\quad(\mu \mathrm{g} / \mathrm{g})\end{array}$ & $\begin{array}{l}\text { No. of } \\
\text { flasks }\end{array}$ & $\begin{array}{c}\text { Progesterone } \\
(\mu g / g)\end{array}$ & $\begin{array}{c}\% \\
\text { increase }\end{array}$ \\
\hline $\mathbf{A}$ & 2 & $235 \cdot 3 \pm 18 \cdot 2$ & 2 & $347.7 \pm 15 \cdot 5^{*}$ & $47.8 \pm 6.6$ \\
\hline $\mathbf{B}$ & 2 & $242 \cdot 0 \pm 6.8$ & 4 & $423 \cdot 3 \pm 15 \cdot 5^{* *}$ & $75 \cdot 0 \pm 5 \cdot 7$ \\
\hline $\mathrm{C}$ & 4 & $116 \cdot 9 \pm 5 \cdot 1$ & 3 & $178 \cdot 0 \pm 13 \cdot 8$ & $52 \cdot 4 \pm 11 \cdot 7$ \\
\hline
\end{tabular}

Significantly different from the control value, ${ }^{*} P<0.05 ;{ }^{* *} P<0.01$.

\section{Discussion}

The prolongation of luteal function in sheep before feto-maternal attachment is dependent on the presence of an embryo in the uterus (Moor \& Rowson, 1966a, b). Mapletoft, Del Campo \& Ginther (1975) have shown that the venous effluent of the gravid uterine horn exerts a luteotrophic effect on the CL. The results of our experiments demonstrate that the ovine preimplantation embryo produces a substance which directly stimulates progesterone synthesis by the corpus luteum. We suggest that this stimulus contributes to the maintenance of preganancy. In addition, we suggest that the luteotrophic properties of this substance are not species specific and that it may be proteinaceous.

We thank Dr D. L. Black for critically reviewing the manuscript and Dr J. B. Marcum for his support and assistance. This project was supported by N.I.H. Grants 2 T01 HD00204-08 and 5 R01 HD08534-03.

\section{References}

Allen, M.W. (1950) A simple method for analyzing complicated absorbtion curves for use in the colormetric determination of urinary steroids. $J$. clin. Endocr. Metab. 10, 71-83.
Greenwald, G.S. \& Rothchild, I. (1968) Formation and maintenance of the corpus luteum in laboratory animals. J. Anim.. Sci. 27, 138-162.

Fujimoto, S., Euker, J.S., RIEGEl, G.D. \& Dukelow, Downloaded from Bioscientifica.com at $04 / 26 / 2023$ 
W.R. (1975) On a substance cross-reacting with luteinizing hormone in the preimplantation blastocyst fluid of the rabbit. Proc. Japan Acad. 51, 123-125.

HANSEL, W. (1971) Survival and gonadotropic responsiveness of luteal cells in vitro. Acta endocr., Copenh., Suppl. 123, 295-317.

HAOUR, R. \& SAXENA, B.B. (1974) Detection of a gonadotropin in the rabbit blastocyst before implantation. Science, N. Y. 185, 444-445.

Heap, R.B., Perry, J.S. \& Rowlands, I.W. (1967) Corpus luteum function in the guinea pig: arterial luteal progesterone levels and the effect of hysterectomy and hypophysectomy. J. Reprod. Fert. 13, 537-553.

Holt, J.A., Heise, W.F., Wilson, S.M. \& KeYes. P.L. (1976) Lack of gonadotropic activity in the rabbit blastocyst prior to implantation. Endocrinology 98, 904-909.

KNOBIL, E. (1973) On regulation of the primate corpus luteum. Biol. Reprod. 8, 246-258.

KREBS, H.A. (1950) Body size and tissue respiration, Biochim. biophys. Acta 4, 249-269.

Mapletoft, R.J., Del CAmpo, M.R. \& Ginther. O.J. (1975) Unilateral luteotropic effect of uterine venous effluent of a gravid uterine horn in sheep. Proc. Soc. exp. Biol. Med. 150, 129-133.

Moor, R.M. \& Rowson, L.E.A. (1966a) The corpus Iuteum of the sheep: functional relationship between the embryo and the corpus luteum. J. Endocr. 34, 233-239.

Moor, R.M. \& Rowson, L.E.A. (1966b) The corpus luteum of the sheep: effect of the removal of embryos on luteal function. J. Endocr. 34, 497-502.

Rowson, L.E.A. \& MooR, R.M. (1967) The influence of embryonic tissue homogenate infused into the uterus, on the lifespan of the corpus luteum in sheep. J. Reprod. Fert. 13, 511-516.

SteEL, R.G.D. \& TORRIE, J.H. (1960) Principles and Procedures of Statistics. McGraw-Hill, New York.

Sudanram, K., Connell, K.G. \& Passantino, T. (1975) Implication of absence of hCG-like gonadotropin in the blastocyst for control of corpus luteum function in pregnant rabbits. Nature, Lond. 256, 739-741.

WiLEY, L.D. (1974) Presence of a gonadotropin on the surface of preimplantation mouse embryos. Nature, Lond. 252, 715-716.

Received 29 March 1978 